\title{
LEKTUR KEAGAMAAN KRISTEN DI MAMASA Christian Religion Literature in Mamasa
}

\author{
Oleh: Idham* \\ *Peneliti pada Balai Penelitian dan Pengembangan Agama Makassar \\ Kantor: Jl. A.P. Pettarani No. 72 Makassar \\ E-mail: $\underline{\text { idbodi@ } \mathrm{vahoo.co.id}}$
}

\begin{abstract}
Abstrak
Salah satu daerah yang masyarakatnya mayoritas beragama Kristen di Kawasan Timur Indonesia adalah Kabupaten Mamasa, Sulawesi Barat. Mamasa yang juga dikenal sebagai Toraja Barat menetapkan tanggal 10 Oktober 1913 sebagai tanggal resmi masuknya agama Kristen di sana. Sebagai daerah yang mayoritas penduduknya menganut agama Kristeh, maka daerah ini disinyalir memiliki banyak lektur keagamaan. Berdasarkanfenomena tersebut, maka tujuan penelitian ini adalah untuk melihat keberadaan, jenis, dan peran lektur keagamaan Kristen di Kabupaten Mamasa. Untuk mendapatkan data tersebut, penelitian ini menggunakan pendekatan kualitatif dengan analisis deskriptif kualitatif. Hasil penelitian menunjukkan bahwa lektur keagamaan Kristen di Mamasa tersebar pada masyarakat, gereja, dan Sekolah Tinggi. Adapunjenis-jenis lektur keagamaan Kristen di Mamasa berisi tentang teologi, sejarah, pemikiran, kidung-kidung, pelajaran sekolah, dan lektur keagamaan Kristen tersebut sangat berperan sebagai media tranformasi keilmuan.
\end{abstract}

Kata Kunci: Lektur Keagamaan, Lektur Kristen, Mamasa

\section{Abstract}

One of the areas where people are predominantly Christian in Eastern of Indonesia is Mamasa regency, West Sulawesi. Mamasa commonly referred to as the West Toraja that set on October 10, 1913 as the official date of entry of Christians religion there. As the region where majority of its population are Christianity, then Christianity, then this regency allegedly has a lot of religious literature. Based on this phenomenon, the purpose of this study was to see the existence, type, and the role of Christian religious literature in Mamasa regency. To obtain such data, this study apply a qualitative approach with a qualitative descriptive analysis. From this research found that the Christian religious literature in Mamasa spread in communities churches and the High School. While any kinds oj Christian religious literature in Mamasa contains about theology, history, ideas, ballad, school lessons, and Christian and Christian religious literature was very important role as a medium of scientific transformation.

Keyword Words: Religious literature, Christian literature, Mamasa

PENDAHULUAN

$\mathrm{P}$ ada Tahun Anggaran 2008 sampai 2009, Balai penelitian dan Pengembangan Agama Makassar telah melakukan inventarisasi dan digitalisasi •;ah Klasik Muslim di kawasan timur Indonesia. Hasil inventarisasi tersebut telah digitalkan sekira 520 ruah naskah klasik. Dari hasil penjajakan dan informasi untuk menghindari adanya diskriminasi penelitian teriiadap semua agama di Indonesia, maka pada tahun

I, selain melanjutkan inventarisasi dan digitalisasi r.askah klasik muslim, juga diadakan inventarisasi dan : gitalisasi terhadap lektur keagamaan Kristen di kawasan timur Indonesia. Salah satu kabupaten di kawasan timur Indonesia yang mayoritas penduduknya beragama Kristen adalah Kabupaten Mamasa, yang menjadi sasaran penelitian ini.

Kabupaten Mamasa merupakan salah satu Kabupaten dari lima Kabupaten di Provinsi Sulawesi Barat (kabupaten Polewali Mandar, Majene, Mamuju, dan Mamuju Utara). Kabupaten ini merupakan pemekaran dari kabupaten Polewali Mamasa.' Kabupaten Mamasa adalah daerah pegunungan di Provinsi Sulawesi Barat yang berbatasan langsung dengan Kabupaten Tana Toraja Provinsi Sulawesi Selatan.

Polewali Mamasa merupakan kabupaten Induk, setelah pemekaran, kabupaten induk berubah nama menjadi Kabupaten Polewali Mandar din Kabupaten hasil pemekaran bernama Kabupaten Mamasa berdasarkan UU nomor 11 tahun 2002. 
Mamasa dikenal juga sebagai Toraja Barat karena kesamaan budaya dan Agama mayoritas kedua daerah tersebut.

Sebagai daerah basis Kristen, Mamasa tentu memiliki banyak lektur keagamaan. Lektur keagamaan, baik yang ditulis tangan dan dicetak oleh orang Mamasa sendiri maupun lektur cetakan yang di bawa dari luar. Lektur keagamaan tersebut memegang peranan penting dalam kesuksesan usaha misi. Di dalam lektur keagamaan sebagai warisan masa lalu itu terdapat berbagai karya ilmiah dan petunjukpetunjuk agama yang bernilai tinggi. Lektur keagamaan itu merupakan peninggalan budaya yang sarat dengan informasi masa lampau, terutama dalam masalah pendidikan, pengajaran, dan keilmuan lainnya. Produk masa lampau yang bernilai tinggi masih banyak yang relevan dengan konteks kekinian.

Penelitian dan hasil penelitian lektur keagamaan diharapkan dapat menjadi sarana pengembangan keagamaan yang lapang dan toleran selaras dengan wawasan kebangsaan dan kebhinekaan, menjadi sarana pengembangan pusat-pusat kajian keagamaan dan sumber belajar agama bagi masyarakat, dan menjadi sarana peningkatan ketersediaan dan pemanfaatan sumber-sumber informasi keagamaan dan perpustakaan rumah ibadat.

Diasumsikan banyak dari lektur kegamaan itu yang tidak lagi diterbitkan atau disalin ulang. Lektur tersebut

'-• ' - leh jadi dimasukkan dalam kategori benda g terancam kepunahannya karena termakan - $\quad$ - 3 dan pemeliharaan yang tidak standar. Lektur keagamaan tua atau klasik ini dapat dikategorikan -". -.. Benda Cagar Budaya (BCB) yang harus dilindungi sesuai dengan Undang-Undang Nomor 5

- $\quad-\sim \quad-$ - I. Salah satu langkah perlindungan adalah . . -suri keberadaannyakemudianmenginventarisir daamendigitafkannya. Selain itu, dilakukan pemetaan ••inkmengungkap kandungannya.

Berdasarkan latar belakang di atas, maka

- van ini mengangkattigapertanyaanpenelitian,

>ahu: 1) Bagaimana keberadaan lektur Kristen di

---- Z) Jenis-jenis lektur Kristen apa saja yang sempat diinventarisir dan digitalkan di Kabupaten Mamasa? dan 3) Bagaimanakah peran lektur Kristen sebagai media tranformasi keilmuan?

Adapun tujuan penelitian ini adalah untuk menjawab pertanyaan di atas, sementara kegunaannya adalah adanya lektur yang terinventarisasi dapat dijadikan sebagai referensi dan untuk hasil digitalisasi berguna untuk penyelamatan lektur keagamaan Kristen.

Penelitian ini adalah penelitian kualitatif. Sebagaimana lazimnya dalam penelitian kualitatif, datadata yang terhimpun secara keseluruhan dianalisis secara deskriptif kualitatif. Adapaun teknik pengumpulan data yang dilakukan adalah: a) Wawancara kepada para pendeta, tokoh masyarakat, pengurus GTM (Gereja Toraja Mamasa), dan pengurus BKSG (Badan Kerjasama Gereja-Gereja) Kabupaten Mamasa, b) observasi terhadap kehidupan keagamaan masyarakat dan terhadap lingkungan lektur, dan c) dokumentasi terhadap lektur keagamaan Kristen Mamasa dengan menggunakan alat perekam elektronik (digitalisasi)

\section{PE M B A H A S A N}

\section{Agama Kristen di Mamasa}

Penyebaran Agama Kristen di Tanah Mandar dimulai dari Mamasa, yang oleh Belanda disebut sebagai Toraja Barat. Dari Mamasa, Agama Kristen kemudian tersebar ke beberapa wilayah PUS seperti Bambangbuda, Galumpang, Bulo, Mala'bo, Mambi dan sebagainya. Penyebaran Injil di Mamasa dilakukan pertama kali oleh GPI (Gereja Protestan Indonesia) pada akhir tahun 1912. Tokoh utama GPI yang melakukan penyebaran Kristen adalah Kyftenbelt. Meskipun status GPI tidak tepat untuk melakukan Penyebaran Injil berdasarkan aturan-aturan Belanda, namun karena NZG (Nederlands Zendelings Genootschaps) tidak memiliki sumber dana yang memadai untuk melakukan penyebaran Injil di wilayah Toraja, Kyftenbelt melakukan inisiasi untuk melakukan penyebaran Injil di bawah bendera GPI dibantu beberapa orang guru sekolah yang merangkap menjadi guru gereja.

Mamasa masuk dalam teritoial Mandar Lama, tapi banyak warga masyarakat Mamasa yang tidak mau dikatakan Mandar. . - - -.J disebut Toraja Barat karena persamaan Agama dan budaya Ini pula yang menjadi salah satu pemicu sehingga terjadi Konflik $£ \mathrm{H} \mathrm{i}$ paaa saat pemekaran wilayah Kabupaten Mamasa dari Kabupaten Polewali Mamasa (Polewali Mandar). Lihat Idham. 2009. Dinamika ...-- -. iflik di ATM fkecamatan Aralle, Tabulation, dan Mambi) Provinsi Sulawesi Barat. Disertasi Makassar Program Pascasarjana $-\quad$ iflik di ATM fkecamatan Aral
- $\quad$ Makassar. (PPs UNM).

Itho Mudzhar. 2009. Pengembangan Jaringan Riset dalam rangka penguatan peran Agama dalam pembangunan Nasional, Jakarta: -... - - L.ima Badan Litbang dan Diklat. h. 11-12 
Strategi penyebaran Injil yang dilakukan oleh di Sulawesi pada umumnya melalui jalur - : : \%an. Hal itupulayang dilakukan oleh Kyftenbelt. P*ia tanggal 3 Januari 1913, ia membuka sekolah di Mamasa, Messawa dan Nosu. Pada bulan N: i ember, didirikan pula sekolah Kristen di Pakin, alian dan Orobua. Strategi pendirian sekolah r.:p sangat efektif dalam menarik minat - asyarakat, sehingga tahun-tahun berikutnya Kyftenbelt dan teman-teman tetap menjadikan - : - . - ${ }^{\text {na }}$ sekolah sebagai proyek utama.

ategi Kyftenbelt tampaknya berhasil menarik arga untuk dibaptis menjadi Jemaat Kristen. $1^{\wedge}$ da bulan Oktober, Kyftenbelt melakukan perjalanan fce berbagai daerah di Toraja Barat. Setiap memasuki ar.g-kampung baru, ia selaludisambutbaikoleh $:: ": \ldots$ j.;k sekitar dan beberapa orang di antaranya r.mta untuk dibaptis. Bahkan ia pernah membaptis dehpan puluh orang di Mamasa dan Messawa untuk an anggota Jemaat Kristen. Hal inilah yang - :a?ari sehingga tanggal 12 Oktober 1913 dijadikan hari resmi penyebaran Injil atau hari resmi -asuknya Agama Kristen di Mamasa.

Gerakan penyiaran Agama Kristen dan pekabaran - i i yang dilakukan oleh Kyftenbelt pada tahun-tahun selanjutnya semakin menunjukkan kemajuan yang cukup pesat. Hal ini dapat dilihat dari hasil laporan

:enbelt kepada pemerintah Belanda yang enyatakan bahwa pada tanggal 21 -22 April 1914, ia -.embaptis 523 orang di Ranteliang, kemudian -. raptis 1.957 orang di Mamasa. Pada tanggal 24

I 1914, ia berhasil membaptis sekkar 1.605 orang beberapa di antaranya adalah kepala-kepala lembang) di Orobua. Pada tahun 1915, dibantu oleh pendeta rembantu J. Hessing, Kyftenbelt berhasil membaptis - : ar 3.300 orang. Dan pada akhir tahun itu, tercatat >ekitar 12.000 orang telah berhasil dibaptis.

Keberhasilan Kyftenbelt dan pendeta pembantu Hessing melakukan pembaptisan di Mamasa, Orobua, Messawa dan daerah sekitarnya menjadi iorongan untuk melakukan penyiaran Injil lebih luas iagi ke berbagai wilayah, termasuk kampung-kampung yang merupakan wilayah kekuasaan kesatuan adat PUS. Hal ini terlihat dari keberhasilan pendeta pembantu J. Hessing melakukan pembaptisan lebih dari 1.800 orang pada bulan Juli sampai Oktober 1916 di kampung Galung-Galung, Bambangbuda, Limbadewata, Salubatang, Saludengen, dan Landosdehata yang merupakan bagian wilayah kesatuan adat PUS.

Faktor utama yang memudahkan masyarakat Mamasa dan sekitarnya (termasuk sebagian wilayah PUS) menerima penyiaran Injil adalah anggapan yang berkembang di masyarakat bahwa masuk Kristen merupakan perintah dari pemerintah dan para pimpinan adat berusaha untuk menyenangkan pemerintah Belanda dengan menyertakan warganya dalam prosesi pembaptisan. Itu berarti nilai Kristus tidak subtantif memengaruhi kehidupan mereka. Pada umumnya mereka masih berpegang teguh pada ajaran tradisional mereka, Aluktodolo. Hal itu tampak jelas pada upacara kematian dan pesta panen. Ketika mereka mulai tahu bahwa masuk Kristen bukanlah perintah dari pemerintah tapi insiatif dari Kyftenbelt saja, masyarakat pun mulai malas ke gereja dan enggan memasukkan anak-anak mereka ke sekolah Belanda.

Sem Bombong, seorang pribumi dari Tawalian tercatat sebagai anak lokal pertama yang secara serius menjadi seorang pengikut Kristus. Ia masuk sekolah Zending (sekolah yang dibuka dan dikelola oleh badan Pekabaran Injil) di Tawalian. Pengajaran Kristen tampaknya mengena di hatinya. Ia kemudian memilih Kristen sebagai anutan barunya. Pada tahun 1920, ia secara terbuka mengakui agama Kristen sebagai agamanya, meski tidak disetujui oleh orang tuanya. Berkat bantuan seorang pendeta pembantu di Mamasa dan pendeta GPI di Makassar, Sem Bombong diutus ke STOVIL di Kupang. Pada tahun 1927, ia lulus ujian di STOVIL dan kembali ke Mamasa. Ia kemudian diangkat menjadi guru.

Pada tahun 1928, pekerjaan Pekabaran Injil di Mamasa diambil alih oleh Bikker dari ZCGK (Zending Christelijke Gereformeede Kerk). Bikker lahir pada tanggal 01 Maret 1898 di Noordeloos. Pada tanggal 04 Mei 1917 ia lulus ujian guru. Ia kemudian bekerja sebagai tenaga guru sukarela, memenuhi dinas wajib militer dan bekerja sebagai guru di Effatha (sebuah sekolah Kristen untuk anak-anak tuli). Pada tahun 1920, ia diterima sebagai mahasiswa di Sekolah Teologia

Pdt. Yesaya. Wawancara pada tanggal 17 Oktober 2010 di Mamasa

- Pdt. Daeng Maroa. Wawancara pada tanggal 11 Oktober 2010 di gedung BPS Gereja Toraja Mamasa

- Disadur dari Dra. W.A. Van der Klis. 2007. Datanglah Kerajaan-Mu Lima Puluh Tahun Pekabaran Injil di Toraja Barat, $1913-1963$. Rantepao: Sulo. 
ZCGK di Apeldoorn. Ia menyelesaikan kuliahnya pada tanggal 22 Juli 1926 dengan gelar sarjana muda (kandidat). Ia kemudian segera dipanggil oleh Jemaat Hilversum untuk menjadi pendeta misioner. Tanggal 9 Agustus 1926, Bikker dipanggil oleh Deputaten ZCGK di Indonesia untuk menjadi pendeta di salah satu wilayah di Indonesia.

Pengalihan tugas ini berkaitan dengan pengalihan wewenang tugas pekabaran Injil yang selama ini dilakukan oleh GPI dengan tokoh utamanya Kyftenbelt kepada ZCGK. Bikker yang ditunjuk oleh ZCGK bersama isteri dan anak-anaknya tiba di Mamasa pada tanggal 23 Maret 1928. Bikker melakukan pembaptisan pertama pada tanggal 4 April 1928, dimana ia membaptis sepuluh orang anak termasuk anaknya sendiri, Metje.

Berbeda dengan Kyftenbelt dkk. dari GPI yang hanya menggunakan metode pendidikan dan kunjungan pembatisan saja, Bikker dan ZCGK menggunakan lebih banyak variasi metode untuk mempermantap iman dan memperkuat pengaruh Kristen di Mamasa dan PUS. Beberapa metode yang digunakan adalah pelayanan para guru sebagai guru sekolah dan guru jamaat. Pembinaan guru-guru penginjil melalui konfrensi guru dan kursus guru sekali seminggu (ada juga kursus khusus guru sekolah rakyat), pekabaran Injil melalui khotbah, percakapan dan diskusi, mengadakan sekolah Minggu dan katekisasi," mengadakan buku dan majalah, menggunakan alat audio visual dalam pengajaran dan pekabaran Injil, pelayanan kesehatan, menerima anak dan muda-mudi sebagai anak piara dan sebagainya.

Pada tanggal 29-30 Juni 1928 digelar konfrensi para guru di Toraja Barat yang dilaksanakan di Mamasa. Konfrensi tersebut membicarakan hal-hal teknis yang mendukung pelaksanaan pendidikan baik pendidikan umum maupun pendidikan Injil di Toraja, seperti kemampuan para guru menggunakan Bahasa Tator. Bahkan hal-hal teknis seperti pemeliharaan rumah guru, gedung sekolah, liburan dan lain-lainjuga dibicarakan dalam konfrensi itu.

Pada tanggal 05-10 Desember 1928 diadakan konfrensi kedua. Konfrensi ini dihadiri oleh Controleur Mamasa, R.H. Muler. Saat itu, banyak guru hidup di tempat terpencil dan pekerjaannya berat. Konfrensi ini menjadi tempat mereka untuk rehat sejenak dari rutinitas mereka sebagai guru. Tema pembicaraan utama dalam konfrensi ini adalah persoalan teologia dan (tentu saja) pendidikan. Selain itu dibicarakan pula beberapa hal pokok seperti pandangan terhadap adat masyarakat lokal yang masih sangat kuat, cara mendekati masyarakat secara efektif, perayaan hari Minggu, ajaran ortodoks dan ajaran modern, mendidik jamaat menuju kemandirian, pernikahan, hati nurani, juga pengalaman para guru dalam melaksanakan tugas mereka.

Digelarnya konfrensi untuk para guru menunjukkan bahwa Bikker dan ZCGK memandang strategi pendidikan masih sangat relevan untuk digunakan dalam melakuan pekabaran Injil dan penyebaran Agama Kristen di Toraja Barat seperti yang pernah dilakukan oleh Kyftenbelt dan GPI. Penguatan kapasitas dan penambahan informasi bagi para guru dalam hal ini sangat diperlukan untuk menciptakan guru yang berkualitas dan memiliki komitmen yang kuat terhadap pekerjaan suci yang mereka lakukan.'

Pekabaran Injil di bawah pengelolaan Bikker semakin menunjukkan hasil yang positif. Pada tahun 1928-1931, kepercayaan para guru terhadap pekerjaan Pekabaran Injil semakin meningkat dan para pemimpin rakyat juga mulai ikutterpengaruh. Injil menjadi pokok pembicaraan di kalangan pimpinan spritual Aluktodolo. Hampir tiap minggu, ada seorang atau s'ekelompok penganut aluktodolo yang memeluk Agama Kristen. Bahkan, Bikker sudah mulai membangun gereja di Tawalian yang merupakan gereja pertama di Mandar untuk menampung jemaat yang semakin hari semakin banyakjumlahnya.

Perkembangan pekabaran Injil di Mamasa menuntut kerja yang lebih keras. Kenyataan ini memaksa Bikker untuk meminta bantuan tenaga pendeta untuk membantu tugas-tugas pekabaran Injil di Mamasa dan PUS. Deputaten ZCGK kemudian mengutus pendeta M. Geleijnse untuk mendampingi tugas-tugas Bikker. Geleijnse tiba di Mamasa pada tanggal 15 Januari 1931. Oleh karena keterbatasan kemampuan Bahasa Melayu dan Bahasa Toraja membuat Geleijnse pada awalnya hanya menjadi pendamping Bikker.

Geleijnse lahir pada tanggal 17 Maret 1893 di Zierikzee. Ia pernah bekerja sebagai tukang kayu lalu memiliki toko kayu sendiri, dan kemudian menjadi tukang kayu di sebuah kapal laut. Pada tahun 1924, ia diterima pada Sekolah Teologia ZCGK di Apeldoorn, 
:gai calon utusan Pekabaran Injil. Pada saat itu, ia $>\mathbf{J}$ dah beristeri danmemiliki dua orang anak. Geleijnse $\sim$ engikuti program studi yang terbatas pada teologi biasa. Tanggal 2 Juli 1930, ia lulus ujian dan menjadi

n pendeta khusus bagi Pekabaran Injil".

Pada tanggal 26 Juli 1930, ia memenuhi panggilan emaat Hoogeveen untuk menjadi pendeta Pekabaran Injil. Tanggal 07 Oktober 1930, Geleijnse lulus ujian Klasis dan diizinkan menjadi pendeta Pekabaran Injil d: Mamasa.

Kedatangan Geleijnse ke Mamasa memperingan dan mempermudah tugas Pekabaran Injil Bikker. Daerah pelayanan ZCGK pun dibagi ke dalam dua resor yaitu resor Mamasa dan resor PUS. Wilayah kerja resor Mamasa terdiri atas Mamasa, Tandaangngan. dan Tandasau (juga termasuk Enrekang, Rappang dan Barru). Resor ini dipimpin oleh Bikker dan berkedudukan di Mamasa. Wilayah kerja resor PL'S terdiri atas wilayah PUS, Galumpang, dan Lembang-Lembang (juga termasuk Mamuju, Majene, Polewali, dan Pinrang). Resor ini dipimpin oleh Geleijnse. Pada awalnya resor PUS berkedudukan di Lembang-Lembang, namun tanggal 1 Januari 1935 a:pindahkan ke Mamasa.

Pembagian resor ini tampaknya memberi dampak rositifbagi perkembangan Agama Kristen di PUS dan Mamasa. Tercatat pada tahun 1935 le.bih dari 1000 -ang Galumpang (khususnya di Kampung Bulo dan

1o) pemeluk kepercayaan Aluktodolo masuk Kristen. Geleijnse tidak hanya berhasil membaptis nbuan orang untuk menjadi Kristen, ia juga sukses T.elakukan revolusi kebudayaan dengan meng-.ancurkan begitu banyak benda-benda adat. Di Bulo, sebatang pohon tobarana besaryang selama ini selalu dipakai oleh masyarakat adat untuk upacara-upacara :radisional dan ritual-ritual Aluktodolo ditebang, dan reralatan adat yang ada di bawah pohon itu dibakar. Di lokasi pohon tersebut kelak dibangun sebuah gereja. Van Der Klis senyebutnya sebagai "perlambang

$\sim$ naran Firman Tuhan yang menang di atas kepercayaan Aluktodolo'".

Pekerjaan Bikker di Mamasajuga menunjukkan rerkembangan yang sangat positif. Tanggal $15 \mathrm{Juli}$ 1937 dianggap sebagai hari yang istimewa dalam sejarah Pekabaran Injil di Mamasa. Van Der Klis" menceritakan peristiwa itu sebagai berikut:
Pada hari itu berkumpullah lebih dari 300 orang di gedung gereja lama (yaitu gedung sekolah) di - Mamasa. Hadir keempat parengnge' (kepala distrik) dari Mamasa, Osango, Tawalian, dan Orobua. Hadir juga parengnge' Mala'bo dan parengnge' Tandung, Controleur (petor) Mamasa, yaitu H.J. van Schravendijk, semua guru, majelis gereja serta hampir semua kepala kampung dan kepala adat.

Pada sekitarjam 10.00 pagi sidangdibuka dengan sebuah renungan tentang 2 Kor. 5:20. Sesudah itu, penganut-penganut aluk toyolo diundang untuk mengeluarkan isi hati mereka. Lambat laun mereka mengeluarkan pikiran mereka dan mereka menerangkan keberatan-keberatan mereka. Nyatalah bahwa yang dikhawatirkan terutama ialah hilangnya adat yang sehubungan dengan adat istiadat, khususnya dalam soalkematian. Sampai jam 19.00 (kecualijam makan bersama) diadakan diskusi yang seru. Setelah banyak orang sudah menyatakan bahwa mereka mau menjadi Kristen, parengnge' Osango mulai berkata-kata. Semua orang diam waktu ia bicara. Katanya kepada guru-guru dan majelis jamaat: "Aku memberikan hak padamu untuk mulai sekarang menyampaikan di semua kampung, bahwa parengnge' Osango sudah menjadi Kristen". Sesudah itu,parengnge' - Orobua dan Mamasa memberikan pernyataan yang sama isinya \{parengnge' Tawalian sudah terlebih dahulu masuk Kristen). Sesudah pernyataan itu dikemukakan usul untuk mendirikan tanda sebagai kesaksian kesatuan keempat parengnge' dalam kepercayaan Kristen.

Peristiwa monumental ini disertai dengan realisasi kesepakatan empat parengnge' (Mamasa, Tawalian, Orabua, dan Osango) pada tanggal 31 Juli 1937. Sesudah melakukan kebaktian. Bikker dan para penganut agama Kristen termasuk keempat parengnge' menuju bukit. Di situ didirikan sebuah batu persegi empat yang bertuliskan nama-nama parengnge' dari keempat distrik tersebut. Keempat parengnge' masing-masing berdiri di segi batu dimana nama distrik mereka tertulis.

Setelah berhasil mengembangkan ajaran Kristen di Lembah Mamasa dan sebagaian PUS, Bikker bersama koleganya Geleijnse mulai mengalihkan pro- *lbid h. 80

'Ibid, h. 81 
gram kerjanya kepada pembangunan infrastruktur guna mendukung kelancaran program Pekabaran Injil dan pemantapan iman bagi warga yang telah menyatakan diri sebagai penganut Agama Kristen. Pada tanggal 29 Desember 1938 diresmikan sebuah gereja di Mamasa yang diberi nama Gereja Beatrixkerk. Pada bulan Oktober 1939, diresmikan pula sebuah rumah sakit di Mamasa. Rumah sakit itu diberi nama Rumah Sakit Banoea Mamasa. Dokter Rotty merupakan dokter pertama yang mengabdi di rumah sakit ini. Ia tidak bekerja lama, karena pada tahun 1942 ia meninggal dunia dan dikuburkan di samping gereja Mamasa.

Perkembangan Agama Kristen di Mamasa dan PUS mengalami permasalahan (masa kritis) ketika terjadi peralihan kekuasaan kolonial dari Pemerintahan Belanda ke Pemerintahan Jepang. Pola kebijakan pemerintahan Jepang yang lebih memberi ruang kepada kelompok Islam mengakibatkan terjadinya kemerosotan pelayanan gereja dan pekabaran Injil di masyarakat. Masyarakat Kristen di Mamasa tidak leluasa melakukan peribadatan akibat dari pengaturan dan pengawasan yang ketat dari pemerintahan Jepang, sekolah zending diambil alih, rumah sakit Banoea Mamasa diambil alih, dan beberapa sekolah Belanda ditutup. Bahkan ribuan orang Mamasa diangkut oleh Jepang untuk bekerja secara paksa (romusa) di luar Mamasa. Kebanyakan di antara mereka tidak kembali lagi karena telah meninggal. Hal yang paling menyedihkan bagi warga Kristen Mamasa adalah tertangkapnya dua tokoh Kristen yang paling berpengaruh dan telah dianggap bapak oleh mereka. Kedua tokoh tersebut adalah Bikker dan Geleijnse. ${ }^{10}$

Pasca kemerdekaan, keadaan sosial politik yang paling buruk dan paling kritis dirasakan oleh warga Kristen Mamasa adalah peristiwa DI/TII. Gerakan DI/TII yang mengusung semangat Islam puritan memberi dampak negatif pada kehidupan sosial warga Kristen Mamasa. Beberapa orang tokoh Kristen yang memiliki pengaruh tewas dalam peristiwa itu. Salah seorang di antaranya adalah Sem Bombong yang tewas di Sumarorong. Bombong dikuburkan pada tanggal 8 Mei 1950 di Tawalian. Kedatangan Batalion 710 yang ditugaskan untuk melindungi Mamasa dari serangan DI/TII tampaknya tidak membawa dampak apa-apa, bahkan membuat masyarakat Mamasa semakin terjebak dalam situasi yang mencekam. Ratusan anggota jemaat Gereja Mamasa terbunuh dalam peristiwa ini, dan belasan gereja dibakar dalam peristiwa DI/TII ini."

Pendudukan Jepang yang banyak memenjarakan tokoh-tokoh Belanda yangjuga merupakan tokoh-tokoh Kristen dan pergerakan radikal-destruktif DI/TII yang tampaknya tidak begitu banyak memengaruhi eksistensi agama Kristen di Mamasa dan beberapa wilayah di sekitarnya. Faktor yang memengaruhi kuatnya eksistensi Agama Kristen di Mamasa adalah peran tokoh-tokoh adat yang menjadi pengikut fanatik Agama Kristen dan pendekatan yang dilakukan oleh Bikker dan Geliejnse yang memberi kesan mendalam bagi masyarakat Mamasa. Hal ini yang menyebabkan rekonstruksi masyarakat Kristen Mamasa pasca pendudukan Jepang dan pasca DI/TII mudah untuk dilakukan. Hingga saat ini, Mamasa menjadi satusatunya wilayah kabupaten yang menjadi basis Agama Kristen terkuat di Sulawesi Barat (sebelumnya bersama dengan Tana Toraja, Luwu dan Soppeng di Sulawesi Selatan).

Mengapa ajaran Kristen mudah diterima oleh masyarakat mamas? Menurut Daeng Maroa ${ }^{12}$, agama Kristen mudah diterima oleh masyarat Mamasa karena adanya persamaan dasar ajaran masyarakat mamasa, yakni agama aluktudolo atau mappurondo dengan ajaran Kristen, khususnya masalah keimanan trinitas. Konsep ajaran tersebut dapat dilihat pada table berikut:

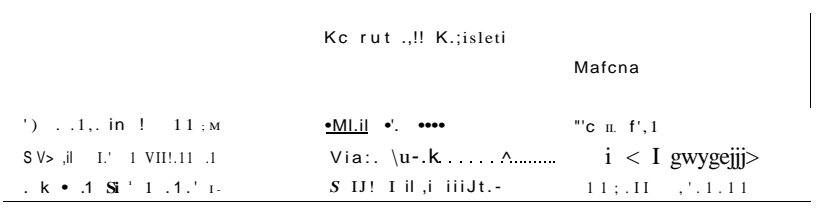

Atas dasar tersebut, maka pemeluk ajaran Kristen berkembang pesat di Mamasa, berikut sekte-sekte ikut berkembang di sana. Adapun sekte-sekte Kristen di Mamasa, antara lain:

GTM (gereja toraja Mamasa)

GBI (gereje Bethel Indonesia)

GPDI (gerejan pantekosta di Indoneisa)

Adven

${ }^{10}$ Pdt. Zakaria. Wawancara pada tanggal 15 Oktober 2010 di Mamasa.

"Van der Kits, loc.cit, h 87

'Pdt. Daeng Maroa. Wawancara pada tanggal 11 Oktober 2010 di gedung BPS Gereja Toraja Mamasa. 
GPT (gereja pantekosta tabernakel)

GTDI (gereja tuhan di Indonesia)

GBT (gereja bethel tabernakel)

GMI (gereja masehi injili)

GT (gereja tuhan)

\section{keberadaan dan jenis lektur Kristen di Mamasa}

Ada 36 lektur keagamaan Kristen yang sempat iiin\entarisir dan didigitalkan di Kabupaten Mamasa.

ektur keagamaan tersebut diperoleh dari para gereja. Sekolah Tinggi Teologia Mamasa M). dan BPS-GTM.

Dari segi umur, lektur dapat digolongkan pada dua - yakni lektur tua dan lektur kontemporer. Lektur tua dibatasi pada umur diatas 50 tahun. Lektur tua ini bisa dalam bentuk cetakan dan tulisan tangan. Lektur tua tulisan angan yang berumur di atas 50 tahun biasa juga disebut naskah klasik. Adapun lektur «.: "temporer adalah lektur yang umurnya kurang dari 50 tahun.

Hasil inventarisasi, pemetaan, dan digitalisasi .ektur keagamaan di Mamasa, telah diinventarisir dan

- talkan lektur keagamaan sebanyak 36 lektur keagamaan. Dari 36 lektur keagamaan tersebut

apat 6 lektur yang tidak diketahui tahun renulisannya, dan dari enam lektur yang tidak iixetahui tahun penulisan tersebut pada umunya ditulis Mngan dan stensilan. Walupun lektur keagamaan ini ndak memiliki tanggal penulisannya, akan tetapi dari kertas yang digunakan dapat disimpulkan bahwa Iektur tersebut belum masuk dalam kategori naskah klasik.

\begin{tabular}{|c|c|c|c|c|c|c|}
\hline Penuis & $\begin{array}{l}\text { Tahun } \\
\text { terbit }\end{array}$ & Judul & $\begin{array}{c}\text { Tern pat } \\
\text { terbrt }\end{array}$ & Penerbit & Jum! hal & Ukuran \\
\hline 'P & Tth & Tafsiran roma & $T p$ & Tp / tu lisan & 18 lembar & $21 \times 16$ \\
\hline \multirow[t]{2}{*}{$T p$} & Tth & $\begin{array}{l}\text { Bulletin (lembaga } \\
\text { penjelilicanan dari } \\
\text { komisi pekabaran } \\
\text { tnjil }\end{array}$ & $T p$ & $T \mathrm{p} / 3$ tens i lan & 42 & $20,5 \times 15,5$ \\
\hline & Tth & Antropologie & $T p$ & $\begin{array}{l}\text { Tp/tulisan } \\
\text { tangan }\end{array}$ & 11 hal & $21,5 \times 14$ \\
\hline $\begin{array}{l}\text { Pdt. G. } \\
\text { Dyke ma }\end{array}$ & Tth & DasarJang Teguh & $T_{p}$ & $T p / s t e n s i l a n$ & 78 & $20,5 \times 15,5$ \\
\hline$T p$ & Tth & \begin{tabular}{|l|}
$\begin{array}{l}\text { Tumbuh dalam } \\
\text { kritus }\end{array}$ \\
\end{tabular} & Mamasa & $T p /$ stensilan & 160 & $21,5 \times 14$ \\
\hline Tp & Tth & \begin{tabular}{|l|} 
GeFedja protestan \\
di Indonesia \\
Baqian Barat
\end{tabular} & Tp & tp & 90 & $20 \times 14$ \\
\hline
\end{tabular}

Keenam lektur keagamaan yang ditulis tangan dan stensilan pada tabel di atas, semuanya menggunakan bahasa Indonesia dengan Ejaan Soewandi.

Dari keenam lektur keagamaan pada tabel di atas, hanya satu lektur yang diketahui penulisnya, yakni lektur nomor empat yang berjudul 'Dasaryang tegulf, lektur ini ditulis oleh Pdt. G. Dykema.
Selain lektur keagamaan yang tidak diketahui tahun penulisannya tersebut di atas, 30 lektur yang lainnya memiliki tahun penerbitan. Tahun penerbitan tersebut mulai dari tahun 1928-1996. Hanya ada enam lektur keagamaan yang berumur 50 tahun atau lebih, yaitu dapat dilihat pada table berikut:

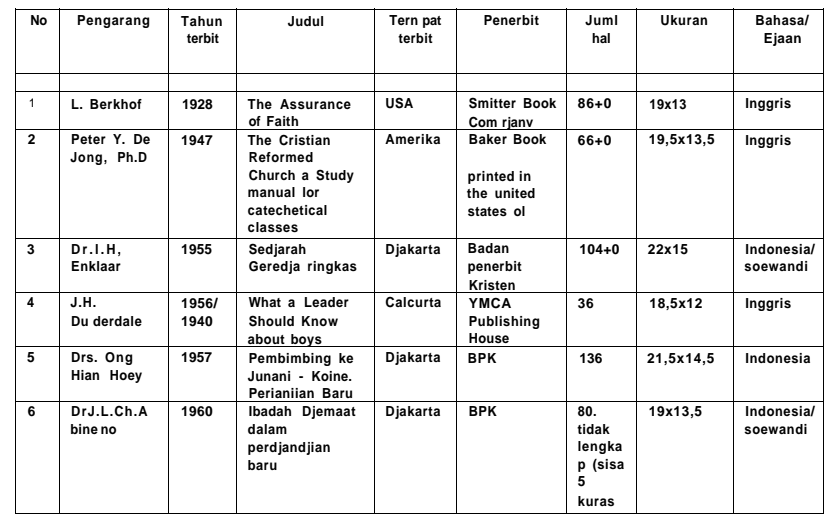

Dari 36 lektur keagamaan Kristen yang sempat diinventarisir dan didigitalkan, lektur tersebut secara gads besar berisi tentang teologi, sejarah, pemikiran, kidung-kidung, dan pelajaran sekolah.

\section{Lektur Kristen sebagai Media Transformasi Keilmuan}

Tak dapat dipungkiri bahwa lektur-lektur terdahulu sangat berperan dalam transformasi keilmuan. Diantara fungsi-fungsi lektur tersebut ialah sebagai rujukan (referensi) penulisan bagi generasi berikutnya, karena bagaimanapun juga, tidak dapat dipungkiri, sebuah ajaran agama hanya akan menjadi sesuatu ajaran agama yang berlalu manakala tidak dapat ditelusuri melalui sebuah referensi yang meyakinkan. Penulisan sejarah dan tulisan ilmiah misalnya mutlak memerlukan referensi yang bisa dipertanggungjawabkan.

Selain itu lektur keagamaan juga menjadi dasar dan dipakai berkhutbah untuk memberikan penerangan kepada masyarakat, karena salah satu cara yang dapat dipakai untuk memberikan argumen kepada ma-syarakat tentang penjelasan sesuatu, tentu berdasarkan kepada lektur. Sehingga masyarakat tidak sekedar menerima 'doktrin' ajaran agama secara emotional, tetapi dapat dilakukan melalui penyadaran secara rasional.

Di Mamasa, tampak para pendeta menjadikan buku-buku atau lektur keagamaan sebagai rujukan dalam kebaktian. Dalam melakukan kegiatan ritual keagamaan, seorang pendeta tentu berdasarkan 
kepada ajaran yang benar-benar ada tertuang di dalam buku-buku yang diakui keabsahannya sehingga tidak akan dicatat sebagai ajaran agama yang keluar dari rel yang ditetapkan. Dengan demikian, lektur keagamaan tersebut berfungsi sebagai penguatan iman, artinya melalui melalui lektur tersebut, seorang yang beragama akan semakin meyakini kebenaran agamanya sebab termaktub di dalam sebuah ajaran suci yang diarsipkan sebagai perpanjangan tangan ajaran yang perlu disampaikan kepada kegenarsi berikutnya.

\section{K E S I M P U L A N}

1. Lektur keagamaan Kristen di Mamasa tersebar pada: Masyarakat, gereja, dan Sekolah Tinggi.

2. Adapun jenis-jenis lektur keagamaan Kristen di Mamasa antara lain: teologi, sejarah, pemikiran, kidung-kidung, pelajaran sekolah.

3. Lektur keagamaan Kristen sangat berperan sebagai media tranformasi keilmuan.

\section{RE K O M E N D A S I}

1. Perlu pelibatan pemerintah (instansi terkait) untuk menginventaris lektur keagamaan Kristen di Mamasa yang masih bersebaran di tengah masyarakat.

1 Perlu penerbitan ulang lektur Keagamaan Kristen tersebut yang masih relevan dengan kondisi kekinian dan penambahan jenis-jenis khazanah lektur keagamaan (kontemporer) di Kabupaten Mamasa.

_ Perlu pengkajian lektur keagamaan Kristen di Kabupaten Mamasa karena sangat berperan sebagai media transformasi keilmuan.

\section{UCAPAN TERIMA KASIH}

Penelitian ini dibiayai oleh DIPABalai Penelitian dan Pengembangan Agama Makassar, Tahun Anggaran 2010. Ucapan terima kasih diperuntukkan kepada Abdul Kadir Massoweang selaku Kepala Balai Penelitian dan Pengembangan Agama Makassar; Prof. Dr. Rahim Yunus selaku konsultan penelitian ini. Selain itu ucapan terima kasih kepada para pendeta di Kabupaten Mamasa, pengurus GTM (Gereja Toraja Mamasa), pengurus BKSG (Badan Kerjasama Gereja-Gereja) Kabupaten Mamasa, serta semua informan yang telah memberikan data-data dalam penelitian ini; juga ucapan terima kasih kepada rekan sejawat yang telah mendukung penelitian ini serta memberikan kritik, saran, dan diskusi mengenai isi tulisan ini.

\section{DAFTAR PUSTAKA}

Idham. 2009. Dinamika dan Resolusi Konflik di ATM (kecamatan Aralle, Tabulahan, dan Mambi) Provinsi Sulawesi Barat. Disertasi. Makassar: Program Pascasarjana Universitas Negeri Makassar. (PPs UNM).

Klis, W.A. Van der. 2007. Datanglah Kerajaan-Mu Lima Puluh Tahun Pekabaran Injil di Toraja Barat, 1913-1963. Rantepao: Sulo.

Mudzhar,Atho. 2009. Pengembangan Jaringan Riset dalam rangka penguatan peran Agama dalam pembangunan Nasional, Jakarta: Departemen Agama Badan Litbang dan Diklat

Undang-Undang Nomor 11 tahun 2002 tentang Pembentukan Kabupaten Mamasa dan Kota Palopo.

Wawancara

Pdt. Yesaya. Wawancara pada tanggal 17 Oktober 2010 di Mamasa Pdt. Daeng Maroa. Wawancara pada tanggal 11 Oktober 2010 di gedung BPS Gereja Toraja Mamasa

Pdt. Zakaria. Wawancara pada tanggal 15 Oktober 2010 di Mamasa. 